\title{
A Review of Tomlinson's Views on Cultural Globalization
}

\author{
Changxue Xue \\ College of Foreign languages, Yanshan University, Qinhuangdao 066004, China \\ Tel: 86-335-805-8710 E-mail: changxue9@hotmail.com
}

\begin{abstract}
By reviewing Tomlinson's views on cultural globalization, this essay explores his contributions by

investigating his work in a critical way. It examines his thoughts of "cultural imperialism" and "cultural globalization", including thematic ideas such as: "complex connectivity", "deterritorialization" and "cosmopolitanism". Then, it discusses the issue weather globalization promises a global culture or a globalized culture in the process of cultural globalization.
\end{abstract}

Keywords: Cultural imperialism, Cultural globalization, Deterritorialization cosmopolitanism

John Tomlinson, Professor in Nottingham Trent University, is the author of Cultural Imperialism and Globalization and Culture that have been translated into many languages such as Chinese, Korean, Japanese and Italian. He is also the author of numerous academic articles and book chapters. The two books of Cultural Imperialism and Globalization and Globalization and Culture show his insightful perspective of cultural imperialism and cultural globalization. Tomlinson is a sagacious thinker who explores globalization across a range of disciplines, including sociology, geography, cultural studies, anthropology, history and communications studies, which makes him a special scholar in the field. His major contribution is that he takes a particular angle to investigate the role of culture in the process of globalization, which is previously neglected.

From "cultural imperialism" to "globalization and culture", the past years have seen the accelerated globalization in which culture is an active element affecting every aspect of the society. This essay explores Tomlinson's contributions by investigating his work in a critical way. It examines his thoughts of "cultural imperialism" and "cultural globalization", including thematic ideas such as: "complex connectivity", "deterritorialization" and "cosmopolitanism". Then, it discusses the issue weather globalization promises a global culture or a globalized culture in the process of cultural globalization.

\section{From cultural imperialism to cultural globalization}

The term "cultural imperialism" appeared in the 1960s in the discourse of intellectual radical criticism. To many readers, it is a simple concept that seems to mean that a country uses its power to spread its culture which might ruin a native culture. A good example is, in china, cultural imperialism is always conveying a negative meaning that is very likely to encounter radical critiques because of the long history of the invasion of imperialism nations. It arouses the feeling of anxiety and uneasiness and this feeling towards imperialism is a part of the whole nation's cultural experience and has been stored in its memory conforming to the identification of the whole nation. Just as Tomlinson (1991) reports, "in the case of cultural imperialism in the Third World, this term might point towards the links between present domination and a colonial past" (p.19). What impresses me here is that, Tomlinson, as a western thinker, is conscious of not taking advantage of dominant and privileged cultural position to look at other cultures, which some western thinkers consider lower ones.

However, cultural imperialism is not so simple as many readers think about it. Tomlinson (1991) makes the point that cultural imperialism is a complex concept that involves how people understand "lived life" and how they look at their particular everyday practice. Besides, the process of disseminating culture is very complex and an economically powerful nation does not necessarily transpose a native culture with its culture. Tomlinson's critical and fresh interpretation of cultural imperialism provides a tool to understand the capitalist modernity which he argues is "technologically and economically powerful but culturally "weak"” (Tomlinson (1991). The term of cultural imperialism makes sense in a particular historical era in which there is distinct difference between America and Europe and Asia. In the 1960s, if a Chinese listened to American music or loved American commodities was considered immoral. With the end of the Cold War, the world changed dramatically. Nowadays, American food, music and films are available all over the China. These American commodities are becoming Chinese favorites and consumption of American commodities has been authentic and everyday practice. Thus, the term, cultural imperialism, is out of date and is problematic because it can't explain what is happening in this society and interpret the cultural meaning at micro level. 
Since the 1990s, the globalization has taken the place of imperialism and has been popular in the academic research and representation of the reality. By studying the definitions given by Ohmae (1995, cited in Tomlinson 1999), Hirst and Thompson (1996, cited in Tomlinson 1999), Tomlinson considers their economic sense of definitions too narrow ones, and brings cultural element to the center of debate. He claims that globalization is multidimensional and "is understood in terms of simultaneous, complexly related processes in the realms of economy, politics, culture, technology and so forth.” (Tomlinson, 1999). Consequently, Tomlinson expanded the term of globalization by defining it as complex connectivity...the rapidly developing and ever-densening network of interconnections and interdependences that characterized modern social life. In his definition, Tomlinson includes aspect of daily life and lay emphasis on the constructing meaning in cultural experience that play an important role in the process of cultural globalization. $\mathrm{He}$ illustrates his ideas by employing a lot of contemporary examples such as traveling by international airplane. Rantanen (2005 p.11) explains that "of these three thinkers (Thompson, Giddens and Tomlinson), Tomlinson is the most optimistic, because for him globalization changes experience." Based on the work of other researchers, one of the most important figure is Giddens who saw globalization as "the consequence of modernity and in turn, modernity as inherently globalizing" (Jung Bong Choi, 2002, p.447), Tomlinson critically absorbs theoretical nutrition of modernity and globalization from him. They both shared the idea of globalization changing the way people live whereas Tomlinson develops the concept of Giddens' work by examining the neglected cultural issues. For Tomlinson, globalization is a "complex connectivity", but it is not in disorder. It is represented in the mechanism of the interaction of all the constituents of politics (power), culture (meaning) and economy (resources) in globalization, but around its core of culture. In this sense, it is cultural globalization.

From cultural imperialism to cultural globalization, globalization has witnessed the development of two different stages. In the meantime, it has also seen the changes of the way the academics and theorists perceive it. Although scholars like Tomlinson has reannotated it, unfortunately, imperialism has ceaselessly been the target of radical criticism since it was born. Because its nature is of being aggressive and expansive culturally, economically and politically and its ambition is to spread "at least, the notion a purposeful project: the intended spread of a social system from one center of power across the globe" (Tomlinson, 1991, p.175). By contrast, the advent of globalization is motivated and mediated by media and technology and it seems to be coherent logic of modernity expanding. I can't be as optimistic as Tomlinson, globalization seems to me that its developmental course is uncertain and ambiguous. There is a lot of different views on it, but with interconnection and interdependence increasing, globalization paradoxically suggests more vulnerability. "According to a recent study, more than $70 \%$ of china's rivers and lakes and $90 \%$ of its aquifers are polluted and more than 300 million people drink substandard water" (30 Jun, 2006). The pollution is caused mainly by production and consumption. However, Consumerist culture spreads all over the world at high speed. Seemingly, people are enjoying the huge variety of fruitful products. Simultaneously, The virtue of being simple, being economical and being endurant is lost. More serious consequences it brings are accelerated pollution and accelerated natural resources crises in this physical world, which is the foundation of cultural activity or may be considered a part of culture. It is obvious that globalization might not produce desirable fruits even from the perspective of culture sphere.

\section{A global culture or a globalized culture?}

It is generally believed that varieties of national and ethnic cultures are made up of a world culture. This conveys the meaning that being national is simultaneously belonging to the world. But accelerated globalization is influencing and transforming the cultures people used to experience in local sense. During the process of globalization, political system and economy system of the world tend to be homogenized. Does this also happen to culture? In view of cultural globalization, a question is always being asked. Does globalization promise a global culture? Reviewing Tomlinson's thematic ideas in terms of globalization and culture facilitates to seek the answers to it. Along with the "complex connectivity", "deterritorialization" and "cosmopolitanism" are two main points in describing and interpreting the cultural globalization.

Traditionally, a culture is closely linked to the places and it is fixed and immovable. Under the conditions of globalization, the relation between the place and culture is reconstructed. "deterritorialization" not only means the travel and transformation of culture but also means everbroadening horizon of mundane experience. (Tomlinson, 1999, cited in Oonk, 2002). Then, the flow of a deterritorialized culture make it possible to transform other cultures of even produce new cultures by hybridity. American popular music like rock and roll and rap spread to china, combined with Beijing Opera, which is represented in a modern and popular style. The new type of music attracts a lot of audience. Tomlinson (1999) explains that deterritorialization may have the potential to generate cosmopolitanism which is described as "cultural deposition", which is not limited to locality, instead, thinks globally and integrates the concerns of others into mundane practices. Tomlinson's view shows his enthusiasm for humanism. In cultural globalization, cosmopolitanism facilitates the mutual understanding, mutual support and increases the sense of responsibility for distant others. But Tomlinson receives critiques from Choi.(2002) because of his insufficient political sensitivity and lack of historical insight into the relationship between nation-state and cosmopolitanism. In my view, "deterritorialization" and "cosmopolitanism" are two active agents in the development of cultural globalization. 
What is a global culture? It refers to "the emergence of one single culture embracing everyone on earth (Tomlinson, 1999, p.71). and replacing the diversity of cultural systems that have flourished up to now". There are different views on the debated issue: Does globalization promise a global culture? Utopian vision of a global culture from Marx's Communist Manifesto to cosmopolitanist thought of Kant and Leibniz is an optimistic imagination of global culture. Though theoretically it is utopian, historically it is put into practice as guidance for people to fight for freedom and liberation for decades of years. It has deep influence in all the aspects of the society. So I think Utopian's theory has its significance in its era. Dystopians are pessimistic about the construction of cultural imperialism which refers to "global capitalist monoculture" and "westernization of the world". As representative of western countries, the US draws on its military and economic power, selling American goods, more importantly its values and its style of living and its culture. Some countries' official language is English rather than one of their native languages such as Sierra Leone. Extending of American cultural has led to cultural homogenization showing American hegemony over some small or poor countries and diversity of culture is weakened and some cultures has perished. Tomlinson expresses (1997: 125) that "a dreadful American mono-culture". Skeptical viewpoints are that the cultural presentation of the realistic world is very complex and there are insufficient evidences to show its emergence.

I share the ideas of skepticism, expanding of modernity doesn't promise a global culture. Anthony Smith (1990) argues a global culture is memoryless because it is not constricted to any particular place and particular group of people. It does not satisfy any living needs and construct any identity. In current stage of globalization, cultural experience and identification change within its coherent logical element such as: "complex connectivity", deterritorialization, hybridity and cosmopolitanism. And also are deeply affected by all constituents of the society such as: politics, economy, environment and technology. Thus, I agree with Tomlinson (1999). Globalization produces a globalized culture rather than a global culture.

\section{Conclusion}

In short, Tomlinson contributes significantly to the theoretic debate of globalization by his insightful perspectives of the cultural conditions of globalization though there are some weaknesses in his arguments. From "cultural imperialism" and "cultural globalization", he developed his ideas in terms of different stages of globalization. Culture is considered a significant element of globalization. By studying the inner logic and outer enviornment of cultural globalization, just as Tomlinson (1999) sees it, globalization produces a globalized culture rather than a global culture.

\section{References}

Choi. J. B. (2002). Critical essays and reviews. Journal of Communication. Inquiry 26 (2) 446-452.

Oonk. G. (2002). Globalization and culture, globalization and identity: dialectics of flow and closure. Journal of World History. pp.532-537.

Rantanen. T. (2005). The Media and Globalization. London: Sage Publications.p.11.Inquiry 26 (2) 446-45.

Smith. A. D. (1990). Towards a global culture. Theory, Culture and Society. Vol. 7, pp.171-191.

Tomlinson, J. (1991). Cultural Imperialism: A Critical Introduction. London: Printer Publisher Ltd.

Tomlinson, J. (1999). Globalization and Culture. Cambridge: Polity Press.

Tomlinson, J. (2005). Global culture, deterritorialisation and the cosmopolitanism of youth culture. Restuating Culture. Council of European Publishing. P21-29.

Tomlinson, J. (1997). Internationalism, globalization and cultural imperialism. In Thompson, K. (ed.) Media and Cultural Regulation. London: Sage/Open Univerisity, pp.117-162.

30 Jun, 2006 Rural China in clean water crisis. [Online] Available:

http://news.bbc.co.uk/nolpda/ukfs_news/hi/newsid_4636000/4636371.stm [Accessed 16 Nov, 2006]. 